\title{
NILAI-NILAI PENDIDIKAN KARAKTER DALAM WARUNG DHUAFA
}

\author{
Milana Abdillah Subarkah \\ abdillahmilana@gmail.com \\ (Dosen Fakultas Agama Islam, Universitas Muhammadiyah Tangerang)
}

\begin{abstract}
Abstrak:
Islam sebagai agama rahmatan lil'alamin telah hadir berabad-abad lamanya dengan tujuan memberikan keselamatan kepada umat manusia. Melalui ajarannya yang komprehensif talah memberikan dampak positif kepada kehidupan masyarakat. Diantaranya dalam manifestasi dari Al-Qur'an Surat Al-Maun Pemuda Muhammadiyah berupaya ikut berkontribusi dalam mengentaskan masalah ditengah-tengah masyarakat melaui program warung dhuafa. Pesan yang fundamental dalam pelaksanaannya terdapat nilai-nilai pendidikan karakter sekaligus pesan dakwah guna terwujudnya masyarakat Islam yang sebenar-benarnya.
\end{abstract}

\section{Kata Kunci: Pendidikan Karakter, Warung Dhuafa}

\section{A. Pendahuluan}

Manusia adalah makhluk sosial, disebut sosial dikarenakan dalam menjalani hidupnya pastilah membutuhkan bantuan atau pertolongan manusia lainnya. Keutuhan manusia akan tercapai apabila manusia sanggup menyelaraskan perannya sebagai makhluk sosial. Sebagai makhluk sosial (homo socialis), manusia tidak hanya mengandalkan kekuatannya sendiri, tetapi membutuhkan manusia lain dalam beberapa hal tertentu. Misalnya, dalam lingkungan manusia terkecil yaitu keluarga. Dalam keluarga, seorang bayi membutuhkan kasih sayang kedua orang tuanya agar dapat tumbuh dan berkembang secara baik dan sehat.

Manusia juga merupakan makhluk yang selalu berinteraksi dengan sesamanya. Manusia tidak dapat mencapai apa yang diinginkan dengan dirinya sendiri. Karena manusia menjalankan peranannya dengan menggunakan simbol untuk mengkomunikasikan pemikiran dan perasaanya. Dalam ajaran Islam pun manusia adalah makhluk yang lemah tak mampu memenuhi kebutuhan hidupnya tanpa bantuan dari pihak lain. Agar dapat memenuhi kebutuhan hidupnya manusia perlu mengadakan kerja sama, tolong menolong, dan bantu membantu dalam berbagai hal. ${ }^{1}$

Dapat diketahui bahwa Islam sangat menjunjung tinggi nilai kebaikan seperti sikap saling tolong menolong. Sikap ini sudah harus menjadi sebuah keharusan Karena Islam merupaka ajaran yang sangat sempurna sebagaimana misinya adalah rahmatan lil'alamin. Allah Swt berfirman dalam Al-Qur'an:

$$
\text { وَمَا أَرْنَسنْنَاكَ إلاَّ رَمْمَةً لِلْعَالَمِيْنَ }
$$

"Dan Tiadalah Kami mengutus kamu, melainkan untuk (menjadi) rahmat bagi semesta alam”. (QS. Al-Anbiya: 107).

Islam mengemban misi memuliakan dan mengangkat harkat dan martabat manusia, menegakkan kebenaran, keadilan, kemanusiaan, demokarsi, egaliter, musyawarah, toleransi, persaudaraan, perdamaian, tolong menolong, rukun, saling menghargai, menghormati,

${ }^{1}$ Arya Bimantara R, "Sifat Ta'awun dalam Kehidupan”, materi Khutbah Jum'at (Yogyakarta, Edisi Desember Majalah Suara Muhammadiyah: 2018), h. 35. 
melindungi, membela yang lemah dan sebagainya. $^{2}$

Sebagai gerakkan dakwah Islam amar ma'ruf nahi munkar yang merupakan organisasi otonom dari Persyarikatan Muhammadiyah, yakni Pemuda Muhammadiyah berinisiasi untuk terus berkontribusi dalam menyi'arkan Islam dengan melalui program warung makan geratis untuk dhuafa. Kegiatan ini merupakan bentuk implementasi sebagaimana yang terkandung dalam AlQur'an Surat Al-maun Ayat 1-3:

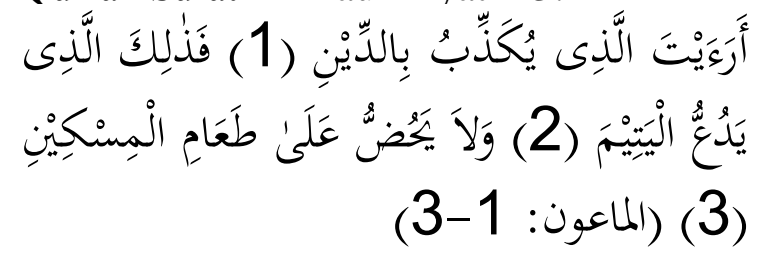

"Tahukah kamu (orang) yang mendustakan agama?. Itulah orang yang menghardik anak yatim, dan tidak menganjurkan memberi Makan orang miskin."

Ketua Pimpinan Pusat Muhammadiyah Hajriyanto Y. Thohari menuturkan, pada abad pertama berdirinya, sebenarnya Muhammadiyah mempunyai trisula pemberdayaan masyarakat. Sula pertama yaitu, pemberdayaan yang dilakukan melalui pendidikan, khususnya untuk kalangan bawah yang tidak punya akses pendidikan. Bagi Muhammadiyah, kata dia, pendidikan sangat penting karena akan melahirkan kesadaran, sehingga umat bisa bangkit dan berjuang untuk mengaktualisasikan dirinya.

Sila kedua yaitu adalah bidang kesehatan. Karena, menurut dia, umat Islam harus sehat dan selalu kuat. Apalagi, kata dia, Nabi Muhammad SAW sendiri telah bersabda bahwa orang mukmin yang kuat itu lebih baik dan lebih dicintai Allah daripada Muslim yang lemah.

\footnotetext{
${ }^{2}$ Abuddin Nata, Studi Islam Komrehensif, (Jakarta, Prenada Media Grup: 2015), Cet. Ke-I, h. 12
}

"Karena itu, disamping kuat dari segi ilmu pengetahuan, umat juga harus kuat secara fisik," ujarnya.

Sila ketiga, gerakan sosial ekonomi, yaitu pemberdayakan yang dilakukan Muhammadiyah dengan membentuk ribuan lembaga mikro keuangan seperti Baitut Tamwil Muhammadiyah (BTM) dan juga koperasi. Dari pembangunan ini, kemudian digunakan untuk mendanai gerakan-gerakan liberasi dan emanaipasi seperti yang disebutkan di atas. ${ }^{3}$

Atas dasar sprit Al-Maun itulah Pemuda Muhammadiyah menginisiasi program Warung Makan gratis untuk dhuafa. Gerakkan ini awal mula didirikan oleh Pimpinan Pusat Pemuda Muhammadiyah pada masa kepemimpinan Dahnil Anzar Simanjuntak, menurutnya program tersebut juga sebagai simbol warna dakwah pemberdayaan dan keberagaman."Karena dakwah itu tidak melulu ceramah dan sebagainya. Salah satu instrumen dakwah adalah membantu yang miskin". 4

Dari ungkapan di atas, Pemuda Muhammadiyah ingin meyampaikan bahwa pendidikan itu suatu aktivitas yang sangat penting sekali, akan tetapi menyampaikan pesan tersebut tidak hanya dalam ruang lingkup lembaga pendidikan formal saja seperti di sekolah, kampus, dan tempat-tempat lembaga pendidikan lainnya. Dalam aktivitas memberikan makan kepada masyarakat dhuafa kegiatan warung dhuafa sangat strategis untuk dapat

\footnotetext{
${ }^{3}$ Khazanah, "Muhammadiyah Berdayakan Umat dengan Spirit Al-Amun", diakses dari https://www.republika.co.id/berita/duniaislam/islam-nusantara/17/09/27/owxlh9396muhammadiyah-berdayakan-umat-dengan-spiritsurah-almaun, pada Sabtu, 19 Januari 2019.

${ }^{4}$ Hidayatullah, "Berdayakan Dhuafa Pemuda Muhammadiyah Buka Waroeng Makan Gratis", diakses dari https://www.hidayatullah.com/berita/nasional/read/ 2017/03/11/113130/berdayakan-dhuafa-pemudamuhammadiyah-buka-waroeng-makan-gratis.html, pada Sabtu, 19 Januari 2019.
} 
disosialisasikan guna memberikan pesan pendidikan karakter didalamnya.

Mengingat pemuda Muhammadiyah prihatin dengan generasi muda saat ini, bahwa banyak generasi muda yang sekarang ini justru melakukan hal-hal yang tidak seharusnya dilakukan oleh suatu generasi harapan bangsa. Bahkan sekarang ini banyak pemuda yang justru merusak masa depan mereka sendiri. Beberapa persoalan yang memberikan bukti bahwa generasi pemuda saat ini bertindak melawan norma-norma yang ada, diantaranya ada sebagian pemuda yang senang mengkonsumsi minuman keras, mengkonsumsi narkoba, melakukan tindak kriminal seperti memperkosa, mencuri, mencopet bahkan merampok. Tidak berhenti sampai disitu, penyimpangan generasi muda juga kerap terjadi dikalangan public figure (artis) yang terlibat kasus prostitusi online yang beberapa waktu lalu terjadi.

Dalam kepriharinan itulah pemuda Muhammadiyah baik di tingkat pusat sampai ke daerah memiliki peranan yang sangat tepat untuk dapat memberikan pendidikan sosial kepada masyarakat atau generasi muda melalui warung dhuafa. Secara eksplisit kegiatan Warung Makan gratis untuk dhuafa ini mampu memberikan nilai-nilai pendidikan karakter. Sekalipun warung dhuafa memprioritaskan kepada kaum dhuafa, tetapi yang bukan dhuafa tetap diperbolehkan untuk mencicipi dan menikmati hidangan makanan yang telah disiapkan oleh warung dhuafa, dengan syarat memberikan infaq seikhlasnya.

Warung dhuafa pertama kali digagas oleh Pimpinan Pusat pemuda Muhammadiyah ketika itu, seiring waktu berjalan kini warung dhuafa sudah tersebar di beberapa kota yang diinisiasi oleh pimpinan-pimpinan daerah pemuda Muhammadiyah. Adapun bebrapa kota diantaranya adalah Aceh, Langkat, Medan, Jakarta, Tangerang, Cirebon, Pemalang,
Pekalongan, Solo, Gresik, Purwakarta, Surabaya, Balikpapan, Palu, dan Bau-bau.

Dengan demikian melalui kesempatan yang baik ini, penulis ingin memaparkan penjelasan tentang pendidikan karakter termasuk dimensidimensi didalamnya dan nilai-nilai pendidikan karakter dalam kegiatan warung dhuafa. Sebagai oraganisasi kemasyarakatan Islam Pemuda Muhammadiyah terus berinovasi dalam mengembangkan dakwah ditengah-tengah kemerosotan nilai-nilai karakter bangsa. Semoga dengan tulisan yang sederhana ini dapat menggugah masyarakat menjadi lebih baik lagi.

\section{B. Pengertian Pendidikan Karakter}

Pendidikan karakter adalah dua kata yang memiliki arti yang berbeda. Pendidikan adalah proses internalisasi budaya ke dalam diri seseorang dan masyarakat sehingga membuat orang dan masyarakat jadi beradab. Pendidikan bukan merupakan sarana transfer ilmu pengetahuan saja, tetapi lebih luas lagi yakni sebagai sarana pembudayaan dan penyaluran nilai (enkulturisasi dan sosialisasi).

Kata pendidikan yang Bahasa Inggrisnya education berarti pendidikan, kata yang semakna dengan education dalam bahasa latinnya adalah educare. Secara etimologi kata Educare dalam memiliki konotasi melatih. Dalam dunia pertanian kata educere juga bisa diartikan sebagai menyuburkan (mengolah tanah agar menjadi subur dan menumbuhkan tana man yang baik). Pendidikan juga bermakna sebuah proses yang membantu menumbuhkan, mendewasakan, mengarahkan, mengembangkan berbagai macam potensi yang ada dalam diri manusia agar dapat berkembang dengan baik dan 
bermanfaat bagi dirinya juga lingkungan sekitarnya. $^{5}$

Sekolah merupakan lembaga akademik dengan tugas utamanya menyelenggarakan pendidikan dan mengembangkan ilmu, pengetahuan, teknologi, dan seni. Tujuan pendidikan, sejatinya tidak hanya mengembangkan keilmuan, tetapi juga membentuk kepribadian, kemandirian, keterampilan sosial, dan karakter. Oleh sebab itu, berbagai program dirancang dan diimplementasikan untuk mewujudkan tujuan pendidikan tersebut, terutama dalam rangka pembinaan karakter.

Semestara itu, Istilah karakter dipakai secara khusus dalam konteks pendidikan baru muncul pada akhir abad18, dan untuk pertama kalinya dicetuskan oleh pedadogik Jerman F.W.Forester. Menurut bahasa, karakter adalah tabiat atau kebiasaan.Sedangkan menurut ahli psikologi, karakter adalah sebuah sistem keyakinan dan kebiasaan yang mengarahkan tindakan seorang individu. Karena itu, jika pengetahuan mengenai karakter seseorang itu dapat diketahui, maka dapat diketahui pula bagaimana individu tersebut akanbersikap untuk kondisi-kondisi tertentu. Istilah karakter juga dianggap sama dengan kepribadian atau ciri atau karakteristik atau gaya atau sifat khas dari diri seorang. ${ }^{6}$

Dalam wacana pendidikan Barat, telah cukup lama dikenal dua istilah yang hampir sama bentuknya dan sering dipergunakan dalam dunia pendidikan, yaitu paedagogie dan paedogogiek. Paedagogieartinya "pendidikan", sedangkan paedogogiek, berarti "ilmu

${ }^{5}$ D. Yahya Khan, Pendidikan Karakter Berbasis Potensi Diri (Yogyakarta: Pelangi Publishing, 2010), h. 1

${ }^{6}$ Sjarkawi, Pembentukan Kepribadian Anak; Peran Moral, Intelektual, Emosional, dan Sosial Sebagai Wujud Membangun Jatidiri, (Jakarta: PT. Bumi Aksara, 2006), h.11 pendidikan". 7 Paedogogiek atau ilmu pendidikan adalah menyelidiki dan merenungkan gejala-gejala atau fenomenafenomena perilaku dalam mendidik.Istilah tersebut berasal dari bahasa Yunani yang asal katanya adalah Paedagogia, yang berarti pergaulan dengan anak-anak. Secara etimologis, paedagogos berasal dari kata paedos (anak) dan agoge (saya membimbing, memimpin). Dengan demikian, paedagogos berarti saya membimbing anak. ${ }^{8}$

Kemudian, studi tentang karakter telah lama menjadi pokok perhatian para psikolog, pedagog, dan pendidik. Apa yang disebut karakter bisa dipahami secara berbeda-beda oleh para pemikir sesuai penekanan dan pendekatan mereka masing-masing. Oleh karena itu, memang tidak mudah menentukan secara definitif apa yang dimaksud dengan karakter. Secara etimologi, akar kata karakter dapat dilacak dari bahasa Inggris: character; Yunani: character, dari charassein yang berarti membuat tajam, membuat dalam. ${ }^{9}$

Menurut Kamus Besar Bahasa Indonesia dimana karakter diartikan sebagai sifat-sifat kejiwaan, akhlak atau budi pekerti yg membedakan seseorang dengan yang lain. Karakter juga bisa diartikantabiat, yaitu perangai atau perbuatan yang selalu dilakukan atau kebiasaan.Karakter juga diartikan watak, yaitu sifat batin manusia yang mempengaruhi segenap pikiran dan tingkah laku atau kepribadian. ${ }^{10}$

M. Furqon Hidayatullah mengutip dari Rutland yang mengemukakan bahwa karakter berasal dari akar kata bahasa Latin yang berarti "dipahat". Sebuah kehidupan, seperti sebuah blok granit dengan hati-hati

\footnotetext{
${ }^{7}$ Ngalim Purwanto, Ilmu Pendidikan Teoritis dan Praktis, (Bandung: Remaja Rosda Karya, 2017), h.1

${ }^{8}$ Ibid. h. 2

${ }^{9}$ Lorens Bagus, Kamus Filsafat, (Jakarta: Gramedia, 2016), h.392

${ }^{10}$ Poerwadarminta, Kamus Besar Bahasa Indonesia (Jakarta: Balai Pustaka, 2015), h.20
} 
dipahat atau pun dipukul secara sembarangan yang pada akhirnya akan menjadi sebuah mahakarya atau puingpuing yang rusak. Karakter,gabungan dari kebajikan dan nilai-nilai yang dipahat di dalam batu hidup tersebut, akan menyatakan nilai yang sebenarnya. ${ }^{11}$

Doni Koesoema memahami bahwa istilah karakter, berasal dari bahasa Yunani "karasso", berarti cetak biru, format dasar. Ia melihat ada dua makna interpretasi dari karakter, yaitu pertama, sebagai kumpulan kondisi yang telah diberikan begitu saja, atau telah ada begitu saja, yang lebih kurang dipaksakan dalam diri kita. Karakter yang demikian dianggap sebagai sesuatu yang telah ada dari sononya (given).Kedua, karakter juga bisa dipahami sebagai tingkat kekuatan melalui mana seseorang individu mampu menguasai kondisi tersebut. Karakter yang demikian ini disebutnya sebagai sebuah proses yang dikehendaki (wiled). ${ }^{12}$

Selanjutnya, perpaduan dua kata antara pendidikan dan karakter memiliki makna yang sangat mendalam jika dipadukan. Adapun pengertian pendidikan karakter menurut para ahli diantaranya sebagai berikut:

Pendidikan Karakter menurut Ratna Megawangi adalah sebuah usaha untuk mendidik anak-anak agar dapat mengambil keputusan dengan bijak dan mengaplikasikan hal tersebut dalam kehidupan sehari-harinya, sehingga mereka dapat memberikan sumbangsih yang positif kepada lingkungan sekitarnya. Nilai-nilai karakter yang perlu ditanamkan kepada anak-anak adalah nilai-nilai universal yang mana seluruh agama, tradisi, dan budaya pasti menjunjung tinggi nilai-nilai tersebut. Nilai-nilai universal ini

\footnotetext{
${ }^{11}$ M. Furqon Hidayatullah, Pendidikan Karakter: Membangun Peradaban Bangsa (Surakarta: Yuma Pustaka, 2010), h.12

${ }^{12}$ Doni Koesoema A, Pendidikan Karakter: Strategi Mendidik Anak di Zaman Global (Jakarta: Gramedia, 2010), h.90-91
}

harus dapat menjadi perekat bagi seluruh anggota masyarakat walaupun berbeda latar belakang budaya, suku, dan agama. ${ }^{13}$

Berdasarkan pilar yang disebutkan oleh Suyanto, pengertian pendidikan Karakter lebih terkait dengan pilar-pilar sebagai berikut, yaitu cinta Tuhan dan segenap ciptaan-Nya, hormat dan santun, dermawan, suka tolong menolong/ kerjasama, baik dan rendah hati. Itulah sebabnya, ada yang menyebutkan bahwa pendidikan karakter adalah pendidikan budi pekerti atau akhlak mulia. Pendidikan karakter dapat di definisikan sebagai suatu metode untuk mengajarkan kebiasaan cara berpikir dan prilaku yang membantu individu untuk hidup dan bekerja sama sebagai anggota keluarga, masyarakat, dan bernegara. Serta membantu mereka utnuk mampu membuat keputusan yang dapat dipertanggung jawabkan.

Menurut Fakhry Gaffar, pendidikan karakter adalah sebuah proses tranformasi nilai-nilai kehidupan kehidupan untuk di tumbuhkembangkan dalam keperibadian seseorang sehingga menjadi satu dalam perilaku kehidupan orang itu. Dalam definisi tersebut ada tiga ide pikiran penting, yaitu: 1) proses transformasi nilainilai, 2) ditumbuh kembangkan dalam kepribadian, dan 3) menjadi satu dalam perilaku. $^{14}$

Pendidikan karakter dalam persepektif Islam memiliki keunikan dan perbedaan dengan pendidikan karakter di dunia Barat. Perbedaan-perbedaan tersebut mencakup penekanan terhadap prinsipprinsip agama yang abadi, aturan dan hukum dalam memperkuat moralitas, perbedaan pemahaman tentang kebenaran, penolakan terhadap otonomi moral sebagai

\footnotetext{
${ }^{13}$ Ratna Megawangi, Pendidikan Karakter Solusi Yang Tepat Untuk Membangun Bangsa, Cet. II (Jakarta: Indonesia heritage Foundation, 2017), h. 93

${ }^{14}$ Mohammad Fakhry Gaffar, Pendidikan Karakter Berbasis Islam (Jogjakarta: Makalah Workshop Pendidikan Karakter Berbasis Agama. 22 Juli 2018), h.4
} 
tujuan pendidikan moral, dan penekanan pahala di akhirat sebagai motivasi prilaku bermoral. Inti dari perbedaan-perbedaan ini adalah keberadaan wahyu Illahi sebagai sumber dan rambu-rambu pendidikan karakter dalam Islam. Akibatnya, pendidikan karakter dalam Islam lebih sering dilakukan secara doktriner dan dogmatis, tidak secara demokratis dan logis. 15

Dengan demikian dapat dikatakan bahwa pada dasarnya pendidikan adalah cermin karakter bangsa. Pendidikan Islam adalah cermin peradaban masyarakat muslim. Hal ini bisa dipahami karena secara psikis seseorang cenderung memasukkan segala sesuatu yang berasal dari luar dirinya seperti simbol-simbol yang mencerminkan dunia di sekitarnya, norma, budaya, kehidupan sosial, serta perilaku orang yang akrab dengannya ke dalam sistem gejala kejiwaannya. Proses internalisasi pengalaman ini kemudian mempengaruhinya dengan cara tertentu ketika memahami, merasa, berpikir dan berbuat. Maka sistem pendidikan tidak lahir dari ruang hampa. Sistem pendidikan lahir dan dimunculkan oleh peradaban tertentu.

Adapun misi atau sasaran pendidikan karakter adalah: Pertama, kognitif, mengisi otak, mengajarinya dari tidak tahu menjadi tahu, dan pada tahap-tahap berikutnya dapat membudayakan akal pikiran, sehingga dia dapat memfungsikan akalnya menjadi kecerdasan intelegensia. Kedua, afektif, yang berkenaan dengan perasaan, emosional, pembentukan sikap di dalam diri seseorang melalui sikap, simpati, antipati, mencintai, membenci,dan lain sebagainya. Sikap ini semua dapat digolongkan sebagai kecerdasan emosional. Ketiga, psikomotorik, adalah berkenaan dengan akction, perbuatan,

\footnotetext{
${ }^{15}$ Abdul Majid dan Dian Andayani, Pendidikan Karakter Perspektif Islam, (Bandung: PT. Remaja Rosdakarya, 2016), Cet. Ke-1, h. 5859.
}

perilaku, dan seterusnya. Pendidikan karakter merupakan jenis pendidikan yang harapan akhirnya adalah terwujudnya peserta didik yang memiliki integritas moral yang mampu direfleksikan dalam kehidupan sehari-hari, baik dalam berinteraksi dengan Tuhan, dengan sesama manusia dan dengan alam lingkungan. Adapun tujuan Pendidikan karakter sebagaimana yang diungkapkan oleh $\mathrm{Ki}$ Hajar Dewantoro adalah "ngerti-ngerasangelakoni"'(menyadari, menginsyafi, dan melakukan). Hal tersebut mengandung pengertian bahwa pendidikan karakter adalah bentuk pendidikan dan pengajaran yang menitikberatkan pada perilaku dan tindakan seseorang dalam mengapresiasi dan mengimplementasikan nilai-nilai karakter ke dalam tingkah laku sehari-hari.

Sementara itu, deskripsi dari masingmasing nilai karakter yang sudah dirumuskan oleh Pusat Kurikulum Badan Penelitian dan Pengembangan Kementrian Pendidikan dan Kebudayaan dapat dilihat dalam tabel berikut ini: ${ }^{16}$

\section{Tabel 2.1}

\section{Daftar Nilai-nilai Karakter berdasarkan} Kemendikbud

\begin{tabular}{|c|c|c|}
\hline $\begin{array}{l}\mathbf{N} \\
\mathbf{0}\end{array}$ & $\begin{array}{c}\text { Nilai } \\
\text { Karakter }\end{array}$ & Deskripsi \\
\hline 1 & Religius & $\begin{array}{l}\text { Sikap dan perilaku yang patuh } \\
\text { dalam melaksanakan ajaran } \\
\text { agama yang dianutnya, toleran } \\
\text { terhadap pelaksanaan ibadah } \\
\text { agama lain, dan hidup rukun } \\
\text { dengan pemeluk agama lain. }\end{array}$ \\
\hline & Jujur & $\begin{array}{l}\text { Perilaku yang didasarkan pada } \\
\text { upaya menjadikan dirinya } \\
\text { sebagai orang yang selalu dapat } \\
\text { dipercaya dalam perkataan, } \\
\text { tindakan, dan pekerjaan. }\end{array}$ \\
\hline & Toleransi & $\begin{array}{l}\text { Sikap dan tindakan yang } \\
\text { menghargai perbedaan agama, } \\
\text { suku, etnis, pendapat, sikap, } \\
\text { dan tindakan orang lain yang } \\
\text { berbeda dari dirinya. }\end{array}$ \\
\hline
\end{tabular}

${ }^{16}$ Bahan Pelatihan Penguatan Metodologi Pembelajaran Berdasarkan Nilai-nilai Budaya untuk Membentuk Daya Saing dan Karakter Bangsa, oleh Pusat Kurikulum Kementrian Pendidikan Nasional, 2010, diakses pada 20 Januari 2019. 


\begin{tabular}{|c|c|c|}
\hline $\begin{array}{l}\mathbf{N} \\
\mathbf{0}\end{array}$ & $\begin{array}{c}\text { Nilai } \\
\text { Karakter }\end{array}$ & Deskripsi \\
\hline 4 & Disiplin & $\begin{array}{l}\text { Tindakan yang menunjukkan } \\
\text { perilaku tertib dan patuh pada } \\
\text { berbagai ketentuan dan } \\
\text { peraturan }\end{array}$ \\
\hline 5 & Kerja keras & $\begin{array}{l}\text { Tindakan yang menunjukkan } \\
\text { perilaku tertib dan patuh pada } \\
\text { berbagai ketentuan dan } \\
\text { peraturan }\end{array}$ \\
\hline 6 & Kreatif & $\begin{array}{l}\text { Berpikir dan melakukan } \\
\text { sesuatu untuk menghasilkan } \\
\text { cara atau hasil baru dari sesuatu } \\
\text { yang telah dimiliki. }\end{array}$ \\
\hline 7 & Mandiri & $\begin{array}{l}\text { Sikap dan perilaku yang tidak } \\
\text { mudah tergantung pada orang } \\
\text { lain dalam menyelesaikan } \\
\text { tugas-tugas }\end{array}$ \\
\hline 8 & Demokratis & $\begin{array}{l}\text { Cara berfikir, bersikap, dan } \\
\text { bertindak yang menilai sama } \\
\text { hak dan kewajiban dirinya dan } \\
\text { orang lain }\end{array}$ \\
\hline 9 & $\begin{array}{l}\text { Rasa ingin } \\
\text { tahu }\end{array}$ & $\begin{array}{l}\text { Sikap dan tindakan yang selalu } \\
\text { berupaya untuk mengetahui } \\
\text { lebih mendalam dan meluas } \\
\text { dari sesuatu yang dipelajarinya, } \\
\text { dilihat, dan didengar }\end{array}$ \\
\hline 10 & $\begin{array}{l}\text { Semangat } \\
\text { kebangsaan }\end{array}$ & \begin{tabular}{lrr} 
Cara berpikir, bertindak, dan \\
berwawasan & \multicolumn{2}{r}{ yang } \\
menempatkan & kepentingan \\
bangsa dan & negara di atas \\
kepentingan & diri & dan \\
kelompoknya & &
\end{tabular} \\
\hline 11 & $\begin{array}{l}\text { Cinta tanah } \\
\text { air }\end{array}$ & \begin{tabular}{lrr} 
Cara berpikir, bertindak, dan \\
berwawasan & \multicolumn{2}{c}{ yang } \\
menempatkan & kepentingan \\
bangsa dan negara di atas \\
kepentingan diri \\
kelompoknya.
\end{tabular} \\
\hline 12 & $\begin{array}{l}\text { Mengharga } \\
\text { i prestasi }\end{array}$ & $\begin{array}{l}\text { Sikap dan tindakan yang } \\
\text { mendorong dirinya untuk } \\
\text { menghasilkan sesuatu yang } \\
\text { berguna bagi masyarakat, dan } \\
\text { mengakui, serta menghormati } \\
\text { keberhasilan orang lain. }\end{array}$ \\
\hline 13 & $\begin{array}{l}\text { Bersahabat } \\
\text { /komunikat } \\
\text { if }\end{array}$ & $\begin{array}{l}\text { Sikap dan tindakan yang } \\
\text { mendorong dirinya untuk } \\
\text { menghasilkan sesuatu yang } \\
\text { berguna bagi masyarakat, dan } \\
\text { mengakui, serta menghormati } \\
\text { keberhasilan orang lain. }\end{array}$ \\
\hline 14 & $\begin{array}{l}\text { Cinta } \\
\text { damai }\end{array}$ & $\begin{array}{l}\text { Sikap dan tindakan yang } \\
\text { mendorong dirinya untuk } \\
\text { menghasilkan sesuatu yang } \\
\text { berguna bagi masyarakat, dan } \\
\text { mengakui, serta menghormati } \\
\text { keberhasilan orang lain }\end{array}$ \\
\hline
\end{tabular}

\begin{tabular}{|c|c|c|}
\hline $\begin{array}{l}\mathbf{N} \\
\mathbf{0}\end{array}$ & $\begin{array}{c}\text { Nilai } \\
\text { Karakter }\end{array}$ & Deskripsi \\
\hline 15 & $\begin{array}{l}\text { Gemar } \\
\text { membaca }\end{array}$ & $\begin{array}{l}\text { Kebiasaan menyediakan waktu } \\
\text { untuk membaca berbagai } \\
\text { bacaan yang memberikan } \\
\text { kebajikan bagi dirinya }\end{array}$ \\
\hline 16 & $\begin{array}{l}\text { Peduli } \\
\text { lingkungan }\end{array}$ & $\begin{array}{l}\text { Sikap dan tindakan yang selalu } \\
\text { berupaya mencegah kerusakan } \\
\text { pada lingkungan alam di } \\
\text { sekitarnya, } \\
\text { mengembangkan upaya-upaya } \\
\text { untuk memperbaiki kerusakan } \\
\text { alam yang sudah terjadi. }\end{array}$ \\
\hline 17 & $\begin{array}{l}\text { Peduli } \\
\text { sosial }\end{array}$ & $\begin{array}{l}\text { Sikap dan tindakan yang selalu } \\
\text { ingin memberi bantuan pada } \\
\text { orang lain dan masyarakat yang } \\
\text { membutuhkan }\end{array}$ \\
\hline 18 & $\begin{array}{l}\text { Tanggung } \\
\text { jawab }\end{array}$ & $\begin{array}{l}\text { Sikap dan perilaku seseorang } \\
\text { untuk melaksanakan tugas dan } \\
\text { kewajibannya, yang seharusnya } \\
\text { dia lakukan, terhadap diri } \\
\text { sendiri, masyarakat, } \\
\text { lingkungan (alam, sosial dan } \\
\text { budaya), negara dan Tuhan } \\
\text { Yang Maha Esa }\end{array}$ \\
\hline
\end{tabular}

\section{Nilai-Nilai Pendidikan Karakter dalam Waroeng Dhuafa}

Warung gratis untuk dhuafa yang digagas oleh Pemuda Muhammadiyah dan tersebar dibeberapa daerah, merupakan salah satu program dakwah pemuda Muhammadiyah kepada masyarakat khususnya mereka yang dhuafa. disebut Warung dhuafa karena memang penyelenggara memprioritaskan masyarakat yang dhufa sebagai target dakwahnya dan dalam waktu yang bersamaan mengajak kepada kaum muslimin untuk berdonasi mengaktualisasikan jiwa kedermawanan dalam kehidupan sehari-hari. Walaupun hanya memberikan makan setiap Jum'at usai diselenggarakan ibadah Sholat Jum'at berjamaah harapan dari pemuda Muhammadiyah hal ini dapat memberikan kepedulian kepada kaum dhuafa sebagaimana yang tertuang dalam AlQur'an Surat Al-Maun, kemudian melalui program warung dhuafa tersebut terdapat tata tertib yang panitia buat agar masyarakat yang menikmati makan siang dapat mengerti pesan dakwah yang 
disampaikan melalui program warung dhuafa ini. Adapun tata tertibnya adalah Pertama, warung ini gratis hanya untuk dhuafa. Kedua, yang tidak termasuk dhuafa boleh makan dengan membayar infak (tidak ditentukan nominalnya). Ketiga, infak yang diberikan akan dipergunakan untuk kegiatan warung dhuafa pecan berikutnya.

Berdasarkan uraian yang tertera pada tata tertib warung dhuafa, walaupun target dakwahnya adalah mereka yang dhuafa, akan tetapi, yang makan di warung dhuafa tidak hanya mereka yang dhuafa, mereka yang bukan dhuafa juga boleh ikut menikmati makan siang yang telah disiapkan oleh panitia. Kemudian, syaratnya memberikan infak, dan infak yang diberikan untuk kegiatan warung dhuafa pada Jum'at berikutnya.

Warung dhuafa rutin setiap bada sholat Jum'at berjamaah salah satunya di Masjid Raya Al-Azhom Kota Tangerang di prakarsai oleh Pimpinan Daerah Pemuda Muhammadiyah Kota Tangerang. Adapun pelaksanaan yang dilakukan oleh panitia penyelenggara bertujuan untuk syi'ar dakwah Islam serta terdapat beberapa nilai pendidikan karakter di dalamnya sebagaimana dijelaskan di atas diantaranya adalah sebagai berikut:

\section{Nilai Religius}

Religius sebagai salah satu nilai dalam pendidikan karakter dideskripsikan oleh Kemendiknas sebagai sikap dan perilaku yang patuh dalam melaksanakan ajaran agama yang dianut, toleran terhadap pelaksanaan ibadah agama lain, dan hidup rukun dengan pemeluk agama lain. Selanjutnya, Ngainum Naim mengungkapkan bahwa nilai religius adalah peghayatan dan implementasi dari ajaran agama dalam kehidupan sehari-hari. Berdasarkan beberapa pendapat dari para ahli dapat disimpulkan bahwa nilai religious merupakan nilai yangbersumber dari ajaran agama yang dianut sesorang yang dilaksanakan dalam kehidupannya sehari-hari. ${ }^{17}$

Dalam hal ini nilai-nilai religius pada pelaksanaan kegiatan warung dhuafa adalah nilai keikhlasan yang dilakukan oleh para relawan warung dhuafa. Secara harfiyah, ikhlas artinya tulus dan bersih. Adapun menurut istilah, ikhlas ialah mengerjakan sesuatu kebaikan dengan semata-mata mengharap rida Allah SWT. Bagi orang yang ikhlas, suatu perbuatan baik tidak harus dikaitkan dengan imbalan atau balasan, melainkan semata-mata ingin mendapatkan rida Allah SWT. Jadi meskipun tidak mendapat imbalan apa pun dan dari pihak mana pun, akan tetap melakukan perbuatan baiknya tersebut.

Ikhlas sangat erat hubungannya dengan suatu amal perbuatan dan amal ibadah. Ikhlas yang sebenarnya adalah ikhlas karena Allah SWT saja. Sebesar apapun suatu amal tampak dimata manusia jika tidak adanya keikhlasan di dalam hatinya, maka amalan itu tidak ada artinya dihadapan Allah SWT. Kemudian, amalan sekecil apapun jika ditunaikan dengan ikhlas hanya semata-mata mengharap keridhaan dan cinta Allah, sungguh amat mulia amalan kecil tersebut. Ilmu ikhlas dalam Islam menekankan untuk senantiasa memurnikan dari polusi, membebaskan dari segala yang merusak niat dan tujuan dalam melaksanakan suatu amalan.

Allah SWT menyeru umat Islam untuk selalu ikhlas dalam beramal, khususnya dalam beribadat kepada-Nya Sebagaimana firman Allad dalam AlOur'an Surat Az-zimar avat 2:

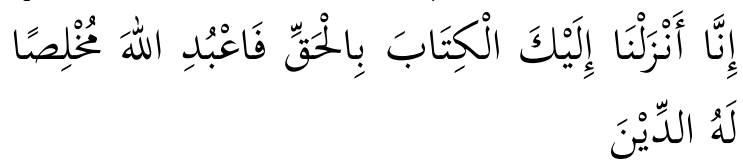

Sesunguhnya Kami menurunkan kepadamu kitab (Al Quran) dengan (membawa)

\footnotetext{
${ }^{17}$ Annis Titi Utami, "Pelaksanaan Nilai Religius Dalam Pendidikan Karakter Di SD Negeri 1 Kutowinangun Kebumen", (Jurnal: Universitas Negeri Yogyakarta, Vol. 16 No. 1 Tahun 2015), h. 645 .
} 
kebenaran. Maka sembahlah Allah dengan memurnikan ketaatan kepada-Nya.

Dalam proses penyelengaraan warung dhuafa senantiasa melibatkan beberapa relawan, mulai dari yang memasak sampai kepada yang menyiapkan berbagai perlengkapan logistik seperti memasang tenda dan membagikan makanan. Relawan tersebut melibatkan dirinya tanpa diperintah oleh siapapun serta kertelibatannya merupakan atas inisiatif dirinya sendiri yang semata-mata hanya ingin mengharap Ridha Allah Swt. Upaya tersebut untuk memurnikan ketaatan kepada Allah menjadi prinsip utama sebagaimana perintah ajaran Islam yang memotivasi umatnya agar senantiasa berbuat ikhlas dalam melakukan amal sholeh.

\section{Nilai Kejujuran}

Kejujuran adalah salah satu dari nilai karakter yang harus dimiliki oleh setiap muslim dan menjadi semakin penting selama ini Indonesia dikenal sebagai bangsa yang masih menjaga kultur ketimurannya, dimana nilai dan akhlaklah yang menjadi dominan dengan karakter dan identitas bangsa ini berada pada dan akhlak itu sendiri.

Kejujuran adalah kunci untuk percaya. Saat seseorang melakukan sesuatu dengan kejujuran, maka ia akan memberikan hati dan jiwanya untuk itu. Hal ini tidak hanya meningkatkan kualitas pekerjaan yang dilakukan, namun juga meningkatkan ikatan yang ada dengan orang-orang sekitar. Kemudian juga akan dirasakan oleh orang lain yang mengenalnya karena melihat kejujurannya dan mulai mempercayainya. Jujur, dalam Bahasa Arab dikenal dengan istilah ash shidqu atau shiddiq, memiliki arti nyata atau berkata benar. Artinya, kejujuran merupakan bentuk kesesuaian antara ucapan dan perbuatan atau antara informasi dan kenyataan. Lebih jauh lagi, kejujuran berarti bebas dari kecurangan, mengikuti aturan yang berlaku dan kelurusan hati.
Seseorang yang memiliki sifat jujur akan memperoleh kemuliaan dan derajat yang tinggi dari Allah. Hal ini tercermin dalam firman Allah di surat al Ahzab ayat 35:

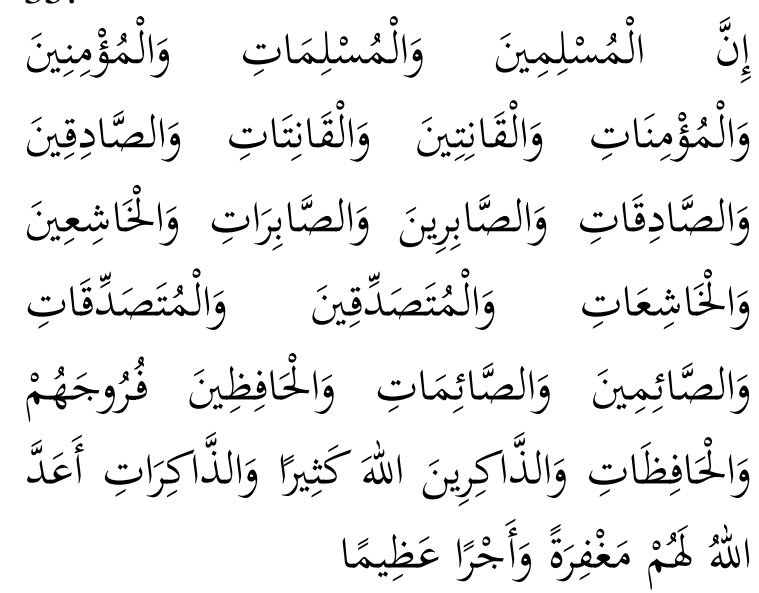

"Sesungguhnya laki-laki dan perempuan yang muslim, laki-laki dan perempuan yang mukmin, laki-laki dan perempuan yang tetap dalam ketaatannya, laki-laki dan perempuan yang benar, laki-laki dan perempuan yang sabar, laki-laki dan perempuan yang khusyuk, laki-laki dan perempuan yang bersedekah, laki-laki dan perempuan yang berpuasa, laki-laki dan perempuan yang memelihara kehormatannya, laki-laki dan perempuan yang banyak menyebut (nama) Allah, Allah telah menyediakan untuk mereka ampunan dan pahala yang besar".

Ayat di atas menegaskan bahwa lakilaki dan perempuan muslim yang tetap berlaku benar atau jujur maka Allah Swt akan memberikan ganjaran ampunan dan pahala yang sangat besar. Selanjutnya, pelaksanaan warung dhuafa yang dibuka setiap hari Jum'at memberikan pengalaman yang positif kepada masyarakat untuk mengaktualisasikan nilai kejujuran. Pertama, dalam upaya kegiatan penggalangan dana yang dilakukan oleh relawan warung dhuafa diantaranya adalah dengan mendirikan "Kulkas kejujuran", dimana produk minuman yang ada di dalam kulkas tersebut keuntungannya dialokasikan untuk kegiatan warung dhuafa setiap Jum'atnya. Kedua, dalam 
tata tertib telah dijelaskan bahwa warung dhuafa tidak hanya diperuntukan kepada yang dhuafa, yang tidak dhuafa juga boleh menikmati makanan yang disediakan selama memberikan infak seikhlasnya. Maka makna dhuafa sesungguhnya kembali lagi kepada siapa yang makan, jika seseorang yang makan dan merasa orang berada pasti akan berinfak dan infak yang diberikan akan dipergunakan untuk kegiatan Jum'at yang akan datang.

\section{Nilai Toleransi}

Dalam Kamus Besar Bahasa Indonesia, toleransi berarti bersifat atau bersikap menghargai, membiarkan, membolehkan pendirian (pendapat, pandangan kepercayaan) yang berbeda atau bertentangan dengan pendirian sendiri. Sesesungguhnya toleransi merupakan salah satu diantara sekian ajaran inti dari Islam. Toleransi sejajar dengan ajaran fundamental yang lain, seperti kasih sayang (rahmah) kebijaksanaan (hikmah), kemaslahatan universal (almaslahah al-ammah), dan keadilan. ${ }^{18}$

Toleransi merupakan salah satu kebajikan fundamental demokrasi, namun ia memiliki kekuatan ambivalen yang termanifestasi dalam dua bentuk: bentuk solid dan bentuk demokratis. Menjadi toleran adalah membiarkan atau membolehkan orang lain menjadi diri mereka sendiri, menghargai orang lain, dengan menghargai asal-usul dan latar belakang mereka. Toleransi mengundang dialog untuk mengkomunikasikan adanya saling pengakuan. Inilah gambaran toleransi dalam bentuknya yang solid. ${ }^{19}$

Selanjutnya, melalui kegiatan warung dhuafa pemuda Muhammadiyah ingin menyampaikan pesan toleransi

\footnotetext{
${ }^{18}$ Zulyadain, "Penanaman Nilai-nilai Toleransi Beragama pada Pembelajaran Pendidikan Agama Islam (PAI)", (Jurnal Pendidikan AlRiwayah, Vol.15 No.1 Tahun 2018), h. 127

${ }^{19}$ Ibid.
}

sebagaimana dijelaskan di atas. Nilai-nilai toleransi menjadi sesuatu yang sangat penting untuk di aplikasikan oleh seluruh lapisan masyarakat, terlebih bangsa Indonesia adalah bangsa yang majemuk yang erat kaitannya dengan beragam perbedaan mulai dari suku, budaya, dan agama. Namun dalam perbedaan tersebut tidak lantas menjadi sebuah permasalahan. Walaupun Warung dhuafa digagas oleh Pemuda Muhammadiyah, akan tetapi makan siang yang disediakan disetiap hari Jum'at bukan hanya diperuntukkan warga Muhammadiyah saja mareka yang masyarakat umum juga boleh menikmati makan siang sekalipu berbeda keyakinan.

\section{Nilai Kreatif}

Kreatif tumbuh dan berkembang karena berada di tempat yang tepat. Proses untuk menjadi kreatif berlangsung terusmenerus dalam diri seseorang. Untuk menjadi kreatif ditunjang oleh karakter. Untuk menjadi kreatif diperlukan watakwatak tertentu sehingga dapat membuat suatu produk kreatif, berupa karya kreatif atau suatu cara untuk pemecahan masalah.

Dalam melakukan aktivitas penggalangan dana untuk kegiatan warung dhuafa, panitia penyelenggara harus menyiapkan sejumlah dana yang tidak sedikit tergantung dari kebutuhan menu dan porsi makanan yang akan disajikan. Dan untuk melakukan hal tersebut para relawan warung dhuafa harus sebisa mungkin mengerahkan kemampuan kreatifitasnya untuk dapat menarik para calon donatur agar berminat berdonasi. Kreatifitas yang dilakukan yakni melalui aplikasi media sosial seperti Instagram, Facebook, Whats App, Youtube, dan media yang lainnya guna mensosialisasikan seluruh program warung dhuafa kepada masyarakat atau para donatur. Setelah aktivitas sosialisasi dilakukan panitia penyelenggara langsung menyiapkan beberapa proposal penggalangan dana serta bisa juga dengan 
cara pendekatan secara personal kepada calon donatur.

\section{Nilai Peduli Sosial}

Kepedulian sosial adalah sikap yang memperhatikan kehidupan bersama sikap ini diwujudkan melalui kepekaan terhadap keadaan orang lain; partisipasi dalam melakukan perubahan yang positif; menolong tanpa pamrih; toleransi; dan empati terhadap penderitaan orang lain. ${ }^{20}$

Kata peduli dalam "Kamus Besar Bahasa Indonesia" berarti memperhatikan atau menghiraukan sesuatu. Kepedulian berarti sikap memperhatikan sesuatu. Dengan demikian kepedulian sosial berarti sikap memperhatikan atau menghiraukan urusan orang lain (sesama anggota masyarakat). ${ }^{2 \mathrm{P}}$ Kepedulian sosial yang dimaksud bukanlah untuk mencampuri urusan orang lain, tetapi lebih pada membantu menyelesaikan permasalahan yang di hadapi orang lain dengan tujuan kebaikan. Maka, dengan memberikan makan siang kepada mereka yang lemah/dhuafa tentu harapannya adalah agar masalah yang dialami oleh mayarakat yakni, mengalami rasa lapar, paling tidak dapat teratasi dengan program jangka pendek warung dhuafa, sehingga mereka yang lapar pada saat itu dapat bertahan sejenak melawan rasa laparnya dan pada akhirnya mereka dapat kembali beraktivitas seperti sediakala. Sebagaimana penjelasan di atas, penulis mencoba menganalisa bahwa kegiatan warung dhuafa yang diinisiasi oleh Pemuda Muhammadiyah di beberapa tempat, memiliki pesan dakwah dan terdapat pula beberapa point nilai-nilai pendidikan karakter yang ditetapkan oleh Kementerian

\footnotetext{
${ }^{20}$ Bambang Rusmakno, dkk., Pendidikan Budi Pekerti; Membangun Karakter dan Kepribadian Siswa (Jakarta: PT Gramedia Widiasarana Indonesia, 2018), h. 42

${ }^{21}$ Hasan Alwi, dkk., Kamus Besar Bahasa Indonesia, ed.3., cet ke-2 (Jakarta: Balai Pustaka, 2002), h. 841
}

Pendidikan dan Budaya Republik Indonesia, terdapat lima point yaitu, Nilai Religius, Nilai Kejujuran, Nilai Toleransi, Nilai Kreatifitas, dan Nilai Peduli Sosial. Tentu melalui dakwah ini paling tidak mampu untuk terus dikembangkan dan disebarluaskan agar semakin banyak masyarakat yang peduli kepada kaum dhuafa, serta dapat juga menginspirasi orang untuk berbuat hal yang sama. Dengan demikian akan semakin banyak kebaikan-kebaikan yang didapat selama masyarakat mampu menjalin hidup yang harmonis, rukun, dan sejahtera. Kepedulias kepada sesame umat manusia akan hadir ketika pemahaman nilai agama telah melekat dalam jiwa seseorang dan pada akhirnya akan terwujud masyarakat Islam yang sebenar-benarnya.

\section{Penutup}

Dari pembahasan mengenai nilainilai pendidikan karakter dalam kegiatan warung dhuafa, maka terdapat beberapa kesimpulan diantaranya sebagi berikut:

Pertama, pendidikan karakter adalah bentuk pendidikan dan pengajaran yang menitikberatkan pada perilaku dan tindakan seseorang dalam mengapresiasi dan mengimplementasikan nilai-nilai karakter ke dalam tingkah laku sehari-hari. sasaran pendidikan karakter adalah: a) kognitif, mengisi otak, mengajarinya dari tidak tahu menjadi tahu, dan pada tahaptahap berikutnya dapat membudayakan akal pikiran, sehingga dia dapat memfungsikan akalnya menjadi kecerdasan intelegensia. b) afektif, yang berkenaan dengan perasaan, emosional, pembentukan sikap di dalam diri seseorang melalui sikap, simpati, antipati, mencintai, membenci,dan lain sebagainya. Sikap ini semua dapat digolongkan sebagai kecerdasan emosional. c) psikomotorik, adalah berkenaan dengan akction, perbuatan, perilaku, dan seterusnya. Pendidikan karakter merupakan jenis pendidikan yang harapan akhirnya adalah terwujudnya peserta didik yang memiliki 
integritas moral yang mampu direfleksikan dalam kehidupan sehari-hari, baik dalam berinteraksi dengan Tuhan, dengan sesama manusia dan dengan alam lingkungan.Adapun tujuan Pendidikan karakter sebagaimana yang diungkapkan oleh Ki Hajar Dewantoro adalah "ngertingerasa-ngelakoni"(menyadari, menginsyafi, dan melakukan).

Kedua, nilai-nilai pendidikan karakter dalam kegiatan warung dhuafa sebagaimana pengamatan dari penulis. Nilai pendidikan karakter diantaranya adalah a) Nilai Religius, b) Nilai Kejujuran, c) Nilai Toleransi, d) Nilai Kreatifitas, dan e) Nilai Peduli Sosial.

\section{DAFTAR PUSTAKA}

Bahan Pelatihan Penguatan Metodologi Pembelajaran Berdasarkan Nilai-nilai Budaya untuk Membentuk Daya Saing dan Karakter Bangsa, oleh Pusat Kurikulum Kementrian Pendidikan Nasional, 2010, diakses pada 20 Januari 2019.

Bambang Rusmakno, dkk., Pendidikan Budi Pekerti; Membangun Karakter dan Kepribadian Siswa, Jakarta: PT Gramedia Widiasarana Indonesia, 2018.

Bimantara R. Arya, "Sifat Ta'awun dalam Kehidupan”, materi Khutbah Jum'at Yogyakarta, Edisi Desember Majalah Suara Muhammadiyah: 2018.

Gaffar. Mohammad Fakhry, Pendidikan Karakter Berbasis Islam, Jogjakarta: Makalah Workshop Pendidikan Karakter Berbasis Agama. 22 Juli 2018.

Hasan Alwi, dkk., Kamus Besar Bahasa Indonesia, ed.3., cet ke-2,Jakarta: Balai Pustaka, 2016.

Hidayatullah,"Berdayakan Dhuafa Pemuda Muhammadiyah Buka Waroeng Makan Gratis", diakses dari

https://www.hidayatullah.com/berita/ nasional/read/

2017/03/11/113130/berdayakan

dhuafa-pemuda-muhammadiyah-

buka-waroeng-makan-gratis.html, pada Sabtu, 19 Januari 2019.

Hidayatullah. M. Furqon, Pendidikan Karakter: Membangun Peradaban Bangsa, Surakarta: Yuma Pustaka, 2010.

Khazanah, "Muhammadiyah Berdayakan Umat dengan Spirit Al-Amun", diakses dari https://www.republika.co.id/berita/du nia-islam/islam-

nusantara/17/09/27/owxlh9396muhammadiyah-berdayakan-umatdengan-spirit-surah-almaun, pada Sabtu, 19 Januari 2019.

Koesoema A. Doni, Pendidikan Karakter: Strategi Mendidik Anak di Zaman Global, Jakarta: Gramedia, 2010.

Majid. Abdul. Dian Andayani, Pendidikan Karakter Perspektif Islam, Bandung: PT. Remaja Rosdakarya, 2016. Cet. $\mathrm{Ke}-1$.

Megawangi. Ratna, Pendidikan Karakter Solusi Yang Tepat Untuk Membangun Bangsa, Cet. II Jakarta: Indonesia heritage Foundation, 2017.

Nata. Abuddin, Studi Islam Komrehensif, Jakarta, Prenada Media Grup: 2015, Cet. Ke-I.

Utami. Annis Titi, "Pelaksanaan Nilai Religius Dalam Pendidikan Karakter Di SD Negeri 1 Kutowinangun Kebumen", Jurnal: Universitas Negeri Yogyakarta, Vol. 16 No. 1 Tahun 2015.

Zulyadain, "Penanaman Nilai-nilai

Toleransi Beragama pada

Pembelajaran Pendidikan Agama Islam (PAI) ”, Jurnal Pendidikan AlRiwayah, Vol.15 No.1 Tahun 2018. 
